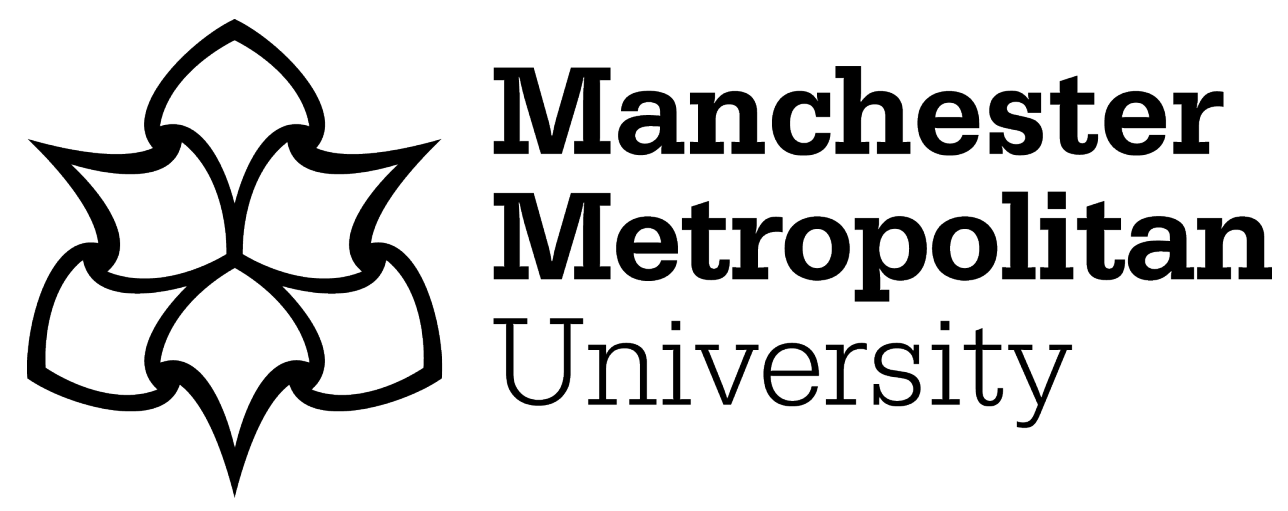

Jayes, Mark ORCID logoORCID: https://orcid.org/0000-0002-0371-7811, Palmer, Rebecca, Enderby, Pamela and Sutton, Anthea (2020) How do health and social care professionals in England and Wales assess mental capacity? A literature review. Disability and Rehabilitation, 42 (19). pp. 27972808. ISSN 0963-8288

Downloaded from: https://e-space.mmu.ac.uk/622452/

Version: Accepted Version

Publisher: Taylor \& Francis

DOI: https://doi.org/10.1080/09638288.2019.1572793

Please cite the published version 


\title{
How do health and social care professionals in England and Wales assess mental capacity? A literature review.
}

Running head: Mental capacity assessment: A literature review

Article Category: Perspectives in Rehabilitation

\begin{abstract}
Purpose: To review evidence describing how health and social care professionals in England and Wales assess mental capacity, in order to identify ways to improve practice.

Methods: A systematised literature review was completed. Electronic databases of published medical, health and social care research and grey literature were searched. Journal articles and research reports published between 2007 and 2018 were included if they met predefined eligibility criteria. Evidence from included studies was synthesised using thematic analysis.

Results: 20 studies of variable methodological quality were included. The studies described assessments carried out by a range of multidisciplinary professionals working with different groups of service users in diverse care contexts. Four main themes were identified: preparation for assessment; capacity assessment processes; supported decision-making; interventions to facilitate or improve practice. There was a lack of detailed information describing how professionals provided information to service users and tested their decisionmaking abilities. Practice reported in studies varied in terms of its conformity to legal requirements.
\end{abstract}

Conclusions: This review synthesised evidence about mental capacity assessment methods and quality in England and Wales and analysed it to suggest ways in which practice might be improved.

\section{Keywords}

mental capacity, decision-making, mental health, learning disability, dementia. 


\section{Introduction}

The involvement of service users in decisions about their treatment and care is essential to the provision of ethical, high quality, person-centred care [1]. Some people require support to make informed decisions or may lack the mental capacity to do so, due to cognitive or communication difficulties that impact on their ability to understand and consider information about a decision to be made, and express their preferences and choices [2]. Estimates of incapacity vary, but a recent review reported that $34 \%$ of hospital patients lacked mental capacity to make decisions about their medical treatment [3].

In England and Wales, the Mental Capacity Act (MCA) [4] provides the legislative framework for assessing mental capacity for people over the age of 16 years. The MCA's five statutory principles establish people's rights to make autonomous decisions, if they are able to do this, and to access support to make decisions, if they need this [5]. The MCA requires health and social care professionals to complete a two-stage mental capacity assessment whenever they have reason to believe an individual may lack capacity to make a specific decision. First, the assessor needs to establish if the individual has an impairment or disturbance of the mind or brain which may affect her/his ability to make the decision [6]. This may be temporary, for example due to the effects of delirium, post-traumatic amnesia or substance misuse, or may result from longer-term mental health or neurological conditions or lifelong conditions such as learning disability (also referred to as intellectual disability in some locations).

Second, if such an impairment or disturbance is present, the assessor should complete a functional test of the individual's ability to: i) understand information relevant to the decision to be made; ii) retain the information; iii) use or weigh the information; iv) communicate a decision using any means [7]. Practical support must be provided to enable the individual to maximise her/his decision-making abilities; for example, information about the required decision should be adapted to make it more accessible to the individual. If the assessor can demonstrate that the individual lacks one or more of these decision-making abilities, because of the impairment or disturbance, s/he should conclude the individual lacks capacity to make the decision. In this situation, the decision can be made by others using a process of "best interests" or substituted decision-making [8].

The results of mental capacity assessments have a direct impact on people's ability to retain independent control over many aspects of their lives, including arrangements relating to medical treatment, care, finances and residence [9]. The findings of mental capacity 
assessments are also used to determine whether a person can be deprived of her/his liberty, in order to remain in a hospital or community care setting, if this is deemed to be in her/his best interests [10]. Consequently, it is imperative that professionals are able to complete accurate evaluations of decision-making abilities and understand their legal obligations when completing capacity assessments.

It has been argued that the MCA has made an important contribution to the promotion and facilitation of shared decision-making in England and Wales, because it places a legal requirement on health and social care professionals to support service users to be active partners in decision-making about treatment and care [11]. At the same time, the MCA and its implementation have been criticised for a number of reasons. The United Nations Committee on the Rights of Persons with Disabilities has challenged the inclusion of a "diagnostic test" within the MCA's prescribed two-stage assessment process, because it argues the test discriminates against people with disabilities [12]. A recent House of Lords review concluded that whilst the MCA legal framework was generally robust (with the exception of the provisions for deprivation of liberty), its implementation had been weak: "Capacity assessments are not often carried out; when they are, the quality is often poor." $[13, p 8]$. Similarly, the emerging case law in this area suggests aspects of practice that require improvement. Judges have criticised assessors for: i) basing judgements of incapacity on subjective perceptions of "unwise" decision-making, rather than the prescribed functional test of decision-making [14]; ii) carrying out generic capacity assessments, instead of separate assessments for specific decisions [15]; iii) failing to provide adequate information to people about decision options and sufficient support to understand this information during capacity assessments [16].

Many health and social care professionals lack awareness of the requirements of the MCA and how to assess capacity and may not be confident about their practice [17]. Professionals report finding capacity assessment particularly challenging when it involves service users who have communication difficulties [18]. Decision-making capacity can be masked by the communication difficulties associated with conditions including stoke, dementia and learning disability. Professionals need to be able to identify and support specific communication needs, in order to complete accurate assessments of decision-making abilities. Individuals with these conditions may also have concomitant cognitive and sensory needs, which professionals also need to address during the assessment process [2]. 
The purpose of this review was to examine evidence describing how health and social care professionals currently assess mental capacity, in order to identify potential ways to facilitate and improve practice. Specifically, the aims of the review were:

1. To understand how health and social care professionals assess mental capacity in England and Wales;

2. To identify approaches or methods that have been developed to facilitate and improve mental capacity assessment in England and Wales.

\section{Methods}

A systematised literature review was carried out to meet the research aims. The review was "systematised" because it used systematic review approaches but involved a single reviewer (the first author) [19]. The reviewer was a practising speech and language therapist with experience of mental capacity assessment in acute hospital settings.

\section{Search strategy and selection criteria}

The search strategy was developed in collaboration with an information specialist (the fourth author). The following electronic databases were searched between April 2007 (when the MCA was implemented) and March 2018: ASSIA via ProQuest, Campbell Library, CINAHL via EBSCO, Cochrane Library, EMBASE, MEDLINE and PsycINFO via OvidSP, Social Services Abstracts via ProQuest and Web of Science. Grey literature was identified using Google Scholar and NHS Evidence searches and through contact with national experts involved in capacity assessment practice and research. References within included records were also searched. The following search terms were identified using the Population, Intervention, Comparator, Outcome, Study design (PICOS) structure [20]: "adults", "mental capacity", "decision making", "informed decisions", "assess", “England", "Wales". The search strategy (available from corresponding author on request) included both free-text and thesaurus searching.

Selection criteria for included studies were developed using the PICOS structure. Records were included if they described mental capacity assessments carried out for adults aged 16 years or above in England and Wales since 2007 or if they described the use of methods to facilitate or improve assessment of capacity. All study designs were included except existing 
literature reviews. Seven literature reviews relating to capacity assessment were identified $[3,21-26]$. Individual studies cited in these reviews were included in the present review if they met the selection criteria. Multiple papers from the same study were included if they contained supplementary original data. Records were excluded if they did not describe mental capacity assessment practice (for example, if they reported investigations of professionals' knowledge of the MCA). Records were also excluded if they described mental capacity assessments completed in other jurisdictions, used assessment instruments developed for use in other jurisdictions, or if they involved assessments of capacity to consent to participate in research. Records reporting legal commentaries or expert opinion were excluded, as were records reported in languages other than English.

\section{Study selection}

The study selection process is reported in a PRISMA (Preferred Reporting Items for Systematic Reviews and Meta-Analyses) flow diagram [27] (figure 1). Duplicate records were removed. Remaining records were screened by title, abstract and full text. Any studies not meeting all the selection criteria were rejected at each stage. The first author consulted the second author in cases when it was unclear whether a record should be included. The second author applied the selection criteria to the record independently, before discussing with the first author whether to include it.

Figure 1 about here

\section{Data extraction, quality assessment and synthesis}

An electronic data extraction form was used to record data relevant to the review question. Several critical appraisal tools were used to assess the quality of included studies, due to the diverse methodologies employed in the studies. The Critical Appraisal Skills Programme checklist for qualitative research [28] was used to assess qualitative designs. Crombie's checklist [29] was used to assess survey and also case note audit/review studies. The Centre for Evidence-Based Management's Critical Appraisal of a Case Study checklist [30] was used to appraise case study and case series designs. No studies were excluded due to low methodological quality. There were insufficient quantitative data to enable a meta- 
analysis of study findings. Therefore, a narrative synthesis of quantitative and qualitative data was completed. Data were analysed and synthesised using Braun and Clarke's [31] thematic analysis method. The researcher examined the data in order to identify codes that could inform the iterative development of a coding framework. Codes represented sections of data with the same or related meaning. These codes were later organised into meaningful conceptual groups, in order to identify emergent themes within the data.

\section{Results}

\section{Study characteristics}

The review identified 22 eligible records describing 20 studies; four records [47,48,52,53] presented data derived from two studies. Individual study aims, designs, methods and key findings are summarised in table 1. The studies were published between 2009 and 2017. Twenty records were published in peer-reviewed journals, whilst the others $[45,52]$ were published as research reports. All studies aimed to provide descriptions of how mental capacity assessments are carried out in practice. Several studies also investigated the quality of assessment practice [32,34,35,37,41,43,45-47,50-52] and the experiences of professionals who complete assessments [34,45,52]. Five studies [35,42,44,47,51] described the effects on practice of an intervention designed to facilitate or improve assessment. Study participants were multidisciplinary health and social care professionals working in both hospital and community settings with a range of service user groups. Studies used quantitative, qualitative and mixed methods designs. Two studies $[34,45]$ used ethnographic methods to collect data about assessment practice; the remaining studies used indirect methods, including single and group interviews, surveys, or audits and reviews of clinical case notes.

Table 1 about here

\section{Methodological quality}

The quality of the included studies varied. As shown in table 1, all studies had methodological weaknesses associated with their designs and methods. All were descriptive studies, involving surveys, qualitative designs, case studies or case series. Most studies directly involving groups of service users, family carers or professionals had relatively 
modest sample sizes (less than 100 participants). Several studies appeared to involve weak sampling strategies. Many records lacked detailed descriptions of data collection and analysis methods and few addressed issues relating to researcher reflexivity. The designs of studies involving novel interventions did not enable the authors to identify causal relationships between the introduction of an intervention and observed changes in practice.

\section{Themes within the evidence}

Thematic analysis identified four overarching themes and 10 subthemes. These are shown in table 2 and described below.

Table 2 about here

\section{Preparing for assessment}

\section{Choice of assessor}

Study records described mental capacity assessments being carried out by a range of health and social care professionals: nurses, occupational therapists (OTs), physicians, physiotherapists (PTs), psychiatrists, psychologists, social care practitioners (including social workers) and speech and language therapists (SLTs). One study [32] also reported the role of care home managers in assessment.

The MCA Code of Practice states that anyone "directly concerned" with an individual can assess her/his capacity to make a decision [54, para 4.38]. However, the final judgement about the individual's capacity should be made by the decision-maker, the person who will make or implement the decision in the individual's best interests, if the assessment concludes s/he lacks capacity [54, para 5.8]. Studies indicated that assessments were not always completed by the decision-maker. In fact, several factors appeared to influence which professionals completed capacity assessments. One factor related to the discipline and seniority of the individual. Three studies $[36,46,47]$ reported data suggesting that assessments tended to be carried out by doctors, especially senior doctors, on behalf of the multidisciplinary team. Community nurses and allied health professionals in an interview study [33] suggested there may be a perception amongst staff that capacity assessments should be completed by specific disciplines, for example medical doctors, psychiatrists and 
social workers. A senior physician in a focus group study [36] suggested that she tended to lead assessments because she wished to protect junior colleagues from a task she perceived to involve a significant amount of responsibility. Community nurses in another study [39] indicated that community health and social care staff might defer to more senior colleagues, for example general practitioners (GPs), to complete mental capacity assessments, if they perceived the assessment process to be difficult or if they lacked confidence in their ability to complete an assessment.

Another potential factor influencing choice of assessor related to the knowledge and skills required to complete capacity assessments for specific types of patient. For example, SLTs might be involved in assessments for people with communication difficulties $[36,40]$. Two studies [36,38] described the involvement of mental health specialists (e.g., liaison psychiatrists or mental health nurses) in capacity assessments for patients with mental health conditions. The authors of two case studies [38] suggested that multidisciplinary assessments of these patients' decision-making abilities were more accurate when they involved psychiatrists with specialist knowledge of mental health presentations. Participants in two studies $[33,36]$ suggested that the choice of assessor could depend on which discipline understood the nature of the decision a patient was being asked to make and the decision options available to her/him. For example, doctors tended to lead assessments for decisions involving treatment options whilst OTs led assessments related to discharge destination decisions.

\section{Information gathering prior to the assessment}

Several studies reported processes of professionals gathering information to help them to prepare for capacity assessments $[32,36,42,44,49]$. Healthcare staff working in a large hospital trust described seeking preparatory information about patients' functional abilities, decision support needs (e.g., about their cognition and communication skills) and decision options [36]. This information was gathered during discussions with other staff and patients' families, and through informal and formal assessments of abilities. Health and social care practitioners working with people with learning disabilities in community settings reported similar processes of information gathering [43]; these participants suggested that finding comprehensive information about the person requiring assessment and the decision itself was an essential but potentially challenging planning activity. 


\section{Capacity assessment processes}

The studies included in this review did not include detailed descriptions of how professionals assessed mental capacity. However, they indicated that capacity assessment could involve both informal and formal processes and that current practice did not always comply with the MCA.

\section{Informal and formal processes}

Informal processes included professionals engaging service users in initial conversations, in order to gain rapport [36] or to provide reassurance to people who might find the assessment process distressing [44]. Initial conversations also helped professionals to gain an informal impression of the person's mental capacity [36]. An ethnographic and interview study [44] identified that professionals working with hospital patients with cognitive difficulties, including dementia, might use information gathered during conversations with a patient over the course of several ward rounds to build up an impression about her/his capacity. These informal assessment processes might take place in conjunction with, or instead of, more formal processes.

Formal processes involved professionals using conversation-format interviews to assess patients' decision-making abilities, as part of the MCA functional test. Five studies $[41,46,47,50,51]$ provided evidence relating to professionals' use of the functional test. There was variability across studies in the extent to which assessments incorporated the test's four criteria (the ability to understand, retain, weigh up information and communicate a decision); the percentage of assessments that appeared to include consideration of these criteria varied from $47.2 \%$ [51] to $100 \%$ [50]. No studies examined in detail how professionals tested decision-making abilities during assessments.

\section{Practice that is not compliant with the MCA}

Several studies $[35,36,43,45,52]$ indicated that formal assessment processes were not always used. Evidence from three studies [33,34,52] suggested formal assessments were often only carried out when patients disagreed with professional recommendations about which decision option might be most suitable. For example, a formal assessment might be triggered only if a patient stated a preference to return to live in her/his own home rather 
than in a care home, as recommended by professionals, or if a patient refused to consent to a medical or care procedure.

Four studies $[36,41,45,52]$ indicated that professionals sometimes based their judgements about mental capacity on people's characteristics, such as their medical diagnosis, cognitive ability or communication skills, rather than on an assessment using the MCA functional test. One of these studies [52] reported that some professionals appeared to make assumptions about people's decision-making capacity on the basis of their dementia or learning disability diagnosis or level of cognitive impairment. The same authors found that professionals sometimes believed erroneously that diagnostic dementia assessments could be used to make judgements about mental capacity, instead of the two-stage capacity assessment.

Two studies [37,52] provided evidence that some professionals confused decision-making capacity with executional capacity (the ability to carry out the outcome of a decision). Professionals in one study [52] reported that they might base capacity assessments for people with dementia on their ability to carry out a functional task related to living independently at home, rather than on their ability to make an informed decision about where to live. Similarly, a study [37] found that social work practitioners commonly confused the inability to manage a personal social care budget with incapacity to make a decision about whether to receive such a budget.

Four studies $(34,41,51,52]$ noted cases where assessors appeared to base their judgements about a person's mental capacity on the nature of the person's preferred decision option, rather than on the results of a two-stage capacity assessment. In one study, certain professionals appeared to base their capacity assessments for hospital patients with dementia or cognitive difficulties on whether or not they felt patients were making unwise decisions [34]. Two studies [51,52] indicated that health and social care professionals were more likely to conclude that a patient lacked capacity if the patient and professionals disagreed about which decision option was in the patient's best interests. This was more likely to happen when professionals perceived the patient's preferred option to carry increased risk [51]. An interview study [41] noted a similar trend for social care professionals to conflate capacity assessment with best interests decision-making, and suggested this was due to a perceived "duty to protect" amongst social care practitioners [41, p.29].

Several studies described professionals making judgements about people's capacity which were then applied to different decisions over time. Over a quarter of respondents to a survey 
of 52 old age psychiatrists [47] stated that they did not routinely carry out separate capacity assessments for different decisions. Similarly, a survey and interview study [52] reported that hospital patients with either dementia or learning disability diagnoses were sometimes subject to a single, generic capacity assessment; some people with profound or severe learning disabilities might be assumed to lack capacity for all decision-making, on the basis of this single, initial assessment.

\section{Supported decision-making}

The studies included in this review provide evidence about the ways that professionals supported people to maximise their decision-making abilities during capacity assessments.

\section{Adjustments to the process}

Nursing and allied health professionals in one study [33] described measures they might take to support decision-making for people with dementia or confusion. These measures included choosing a familiar setting for the assessment, to put the person at ease, or a context that may be relevant to the decision being discussed (for example, a home environment for a decision relating to living at home). Measures also included giving people additional time to make decisions and selecting a time when people could engage better in the assessment process.

\section{Use of information}

The studies indicated that professionals did not always provide clear, explicit information to support patients' decision-making. For example, professionals describing discharge destination options to patients sometimes used the euphemistic expression "somewhere where you can get a bit more help" rather than "a residential nursing home" [34, p.79]. In the same study, some professionals appeared to base their capacity judgements on whether patients could remember previous conversations with staff and were orientated to place, rather than on their ability to understand information relevant to the decision in question.

\section{Supporting people with communication needs}


Several studies described methods professionals used to identify and support people with communication needs during capacity assessments [32,35,42,49,52]. Professionals identified communication needs by gathering information from patients' families, carers or from other staff, by examining healthcare records or through a process of assessment $[32,35,42,49]$. A range of methods appeared to be used to support people's communication needs. These included: using simple spoken language and supplementary communication methods, such as pictures, photographs and drawing [32,36], writing and gesture [36]; adapting written information about decision options to make it more accessible to individual needs [42,49]; referring to an SLT for specialist assessment and support $[36,49]$.

Other studies indicated that people with communication difficulties did not always receive adequate support to make decisions during capacity assessments. Williams et al. [52] identified that, at times, professionals did not appear to take steps to support the communication needs of people with learning disabilities. Furthermore, the routine involvement of SLTs in supporting people with communication needs during capacity assessments appeared inconsistent and perhaps dependent on other professionals being aware of the nature of communication needs and the types of support SLTs could offer $[36,40]$.

Three studies $[33,46,47]$ provided evidence that people who were not native English speakers did not always receive the support they needed during capacity assessments. Two studies investigating the implementation of the MCA for people with mental health needs found that old age psychiatrists did not always consider patients' language needs [46] or did not routinely use interpreters to support patients [47]. An investigation of capacity assessment practice within home care settings [33] found that nursing and allied health professionals did use professional interpreters to support people's language needs at times, but also relied on family members to interpret during assessments. Participants in the study indicated that this approach was not always effective, as it could be difficult to ascertain whether family members provided accurate, objective interpretations during assessments.

\section{Consideration of cultural, ethnic and religious factors}

Chapter three of the MCA Code of Practice (2007) [54] advises those assessing mental capacity to consider "cultural, ethnic or religious factors that shape a person's way of 
thinking, behaviour or communication" [54, p.33]. Two studies [46,47] provided mixed evidence about whether professionals took account of such factors during capacity assessments. The first study [46] reported that assessors appeared to consider these factors in less than half of the patient cases they examined; assessors were more likely to consider cultural, ethnic, religious and linguistic factors for patients from black and minority ethnic groups. A subsequent survey study [47] found more positive results; over $80 \%$ consultants in old age psychiatry reported considering these factors during capacity assessments.

\section{Interventions to facilitate or improve practice}

\section{Use of strategies}

Several studies identified strategies that professionals used to facilitate or improve assessment. These strategies included: allowing adequate time to complete assessments $[33,36,46]$; carrying out serial assessments if necessary $[36,46]$; using a calm environment [46]; involving professionals familiar with and to the person being assessed [36,46,41]. Participants in several studies $[33,36,39,41,44,52]$ identified the benefits of joint assessment or making consensus judgements about capacity as a team. The involvement of families in assessments to manage patient anxiety and facilitate communication with patients was identified as a facilitative factor, but required careful management. Family members might have strong opinions about their relative's mental capacity or about which decision option might be best for her/him; these opinions could lead to behaviour that inhibited or influenced the assessment process $[33,36,44]$.

\section{Use of novel resources}

Several studies described clinical initiatives introduced to facilitate or improve practice. Two studies $[42,49]$ from the learning disability literature described methods to gather preassessment information to guide the assessment process and support the person being assessed. The first study [42] described the creation of screening assessments for cognitive, communication and money skills, which could be used by assessors to tailor the capacity assessment process for decisions relating to entering into tenancy agreements. The findings 
of language and literacy screens could be used to adapt the way assessors provided information about decision options, to make it more accessible to individuals.

The second study [50] described the implementation of a new structured system to guide mental capacity assessments for people being asked to make decisions about whether to have eye surgery. The system involved a two-phase assessment process and incorporated an accessible patient information leaflet and an assessment process flowchart for professionals. The initial screening phase enabled assessors to determine, in a time-efficient way, whether/how to proceed to a more detailed capacity assessment and whether to refer to an SLT for more detailed communication assessment. The system was not formally evaluated but the authors reported two case studies; in one of these, a service user commented that she found the accessible leaflet helped her to remember information about the surgery.

Three studies $[34,35,43]$ reported the implementation of assessment and documentation resources designed to facilitate or improve the assessment process for different clinical groups. One of these studies [43] reported the introduction and evaluation of a structured assessment framework, comprising a checklist designed to support professionals to comply with the requirements of the MCA when assessing people with learning disabilities. Before and after case note audits indicated that practice improved after implementation of the checklist. However, the design of the study makes it difficult to draw any firm conclusions about the intervention's effectiveness.

In the second study [35], a capacity assessment guidance and documentation resource and training package were developed for professionals working with hospital patients with proximal femoral fractures. Again, before and after case note audits suggested that practice improved following introduction of the intervention: professionals completed documentation for more patients and their capacity assessments were more consistent with legal standards. The third study [49] evaluated the effects of an education package on assessment documentation quality. Face-to-face training and written guidance relating to documentation requirements were provided to psychiatrists and psychiatric liaison nurses. A subsequent case note audit did not demonstrate that the intervention had any significant effect on documentation quality.

Three further studies $[34,36,41]$ described positive effects of using documentation proformas. In one study [34], documentation of a single capacity assessment for a patient with dementia appeared comprehensive and consistent with legal requirements when professionals used a new documentation proforma. Participants in another study [41] 
reported that they thought proformas facilitated assessments, improved communication between professionals and helped assessors to feel more confident.

\section{Discussion}

This literature review was designed to increase understanding of how health and social care professionals assess mental capacity using the Mental Capacity Act (2005) [4] legal framework. The review was motivated by the need to identify potential ways to improve mental capacity assessment practice, which a recent House of Lords review judged to be of low quality [13].

\section{Findings and implications}

The review identified 20 studies describing assessments carried out by multidisciplinary health and social care professionals for people with a range of lifelong and acquired neurological and mental health conditions in both hospital and community settings. Most studies did not provide sufficient detail about the methods used by professionals to carry out capacity assessments. Further research is required to identify how professionals provide information to service users about decision options and how they test their decision-making abilities.

Future studies could usefully employ ethnographic methods (as used in [34]) to provide more detailed analysis of assessment processes. Conversation or discourse analysis methodologies could also be used to investigate the components of the mental capacity assessment interview that appear to facilitate or impede service user decision-making and professional judgements about capacity. Such approaches have been used to investigate how professionals facilitate decision-making for patients with intact mental capacity [55]. Future studies should also investigate the perspectives of people with disabilities, or of others who have been assessed as lacking capacity, and their family members and advocates. Three studies $[35,45,49]$ in the review provided only limited data relating to these people's experiences of mental capacity assessment.

The reviewed studies do provide indications of how health and social care professionals approach capacity assessment in England and Wales. Decisions about which disciplines take responsibility for individual assessments appear to be influenced by factors relating to skill mix, perceptions about discipline-specific roles and professional hierarchy. The MCA 
Code of Practice does not associate specific disciplines or levels of seniority with responsibility for capacity assessment; instead, the Code suggests that assessors require sufficient knowledge and skills to help them to understand decision options and know how to support people's decision-making support needs [54, p.53-54]. An assessor needs to understand the range or nature of decision options available to a person in order to provide an accurate assessment of that person's ability to understand and weigh up information relevant to the decision [56]. Similarly, an assessor needs to be aware of how a person's cognitive, communication or mental health needs may impact on decision-making abilities and how these needs can be supported during an assessment. Otherwise, the assessment is likely to be inaccurate [57].

This presents a challenge to professionals, who may not individually possess these diverse types of knowledge and skills. For example, a medical professional may understand information relevant to different treatment options but lack the knowledge, experience and skills to communicate this information to a person with a communication disability. This review suggests that health and social care professionals overcome this challenge by collecting information about decision options and service users' support needs before commencing capacity assessments and/or by completing assessments jointly with colleagues. Two or more professionals can share responsibility for gathering evidence about decision-making abilities and can arrive at a judgement about capacity through a process of consensus. Partnership working between professionals with complementary knowledge and skills is more likely to lead to assessments that are person-centred, valid, reliable and legally compliant [54, p.53-54].

An important finding of this review is that health and social care professionals do not always appear to use the MCA two-stage assessment process to make judgements about capacity, or complete separate assessments for individual decisions at different points in time, as required by law. In the studies reviewed, this was particularly the case for professionals working with people with learning disabilities or dementia. These findings are consistent with trends previously identified by the House of Lords review [13] and have been the focus of judges' criticisms in legal cases [14-16]. This type of practice is incompatible with the MCA's first statutory principle, which requires professionals to assume intact capacity, unless they can demonstrate through the prescribed assessment process that capacity is lacking [5].

When a professional makes a judgement about an individual's mental capacity solely on the basis of her/his diagnosis or level of impairment, that judgement is likely to be inaccurate. This is because a person's inherent decision-making capacity may be masked by outward 
signs of a disability, for example a speech or language disorder [18]. The MCA's decisionspecific, two-stage assessment process safeguards against this. Failure to complete this assessment is unlawful and unethical, because it directly discriminates against people with disabilities; it denies them the right to support with decision-making, to a legally-defined, more standardised capacity assessment and potentially the right to self-determination. As a result, people with disabilities may be asked to make uninformed decisions or may be excluded from decisions about where they live, how they spend their time or how they manage their health and social care needs.

Certain studies included in this review described different methods professionals used to support people with cognitive and communication needs, or those who were not native English speakers, during capacity assessments. However, this type of practice was not consistent across studies. Similarly, healthcare professionals did not always consider the impact on the assessment process of individual differences due to culture, ethnicity or religion. This evidence suggests that current practice may not always be consistent with the MCA's second statutory principle, which requires professionals to provide practical support with decision-making and to make adjustments to the assessment process [5].

Failure to offer this support or make adjustments is discriminatory against people with disabilities and people from different cultural, ethnic and religious backgrounds, whose approach to decision-making may be influenced by particular value systems and ethical frameworks [58]. When people are not enabled to participate meaningfully in decisions about their care, their satisfaction in services and adherence to treatment regimes are reduced and their carers' quality of life and mood are adversely affected [59]. Care providers could face legal challenges by service users and their families and potential financial penalties, if their mental capacity assessments are judged to be inadequate. Furthermore, care regulators might make inferior judgements about the standard of care provided by organisations, if they observe inferior mental capacity assessment practice.

It is possible that professionals do not comply with the MCA because they do not understand their legal obligations [17]. Alternatively, it may be because the MCA [4] and its Code of Practice [54] provide only limited practical guidance about how the prescribed legal standards can be achieved. In the absence of any gold standard assessment method, mental capacity assessment in England and Wales remains "subjective and can be complex" $[60, p 56]$. This review also suggests that professionals may find capacity assessment challenging because the process requires them to reconcile potentially conflicting professional, ethical and legal imperatives to promote service user autonomy and, at the 
same time, act therapeutically towards service users and protect them from harm $[41,44$, 53]. Professional enablement of apparently "unwise" service-user decision-making, as advocated by the MCA, may not be compatible with individual and service level risk-aversive practices [44].

This review provides examples of strategies and interventions developed to facilitate and/or improve practice; these initiatives appear to have been motivated by a recognition that capacity assessment is complex and challenging. The interventions included training and the introduction of practical resources designed to help professionals to structure and document their assessments in line with legal standards and to meet the needs of people with communication disabilities during the assessment process. In addition to supporting professionals to comply with legal standards, the use of these types of interventions may improve the consistency of assessment processes, and impact positively on the intra- and inter-assessor reliability of capacity judgements.

However, there is a lack of high quality evidence that such interventions are effective in improving capacity assessment. The interventions described in this review were designed for local use and do not appear to have been implemented more widely. Studies reported that some professionals had not received training in mental capacity assessment or felt their training needed to be updated [40]. Professionals who had received training reported that they still found capacity assessment challenging [36] and that they would benefit from additional training, especially if it involved discussions about clinical scenarios [39] and practical aspects of assessment [33]. Similarly, participants in studies identified a need for greater access to practical resources to help them to improve their practice [40]. Resources such as documentation aids were not used widely [34] and some staff who did use them appeared ambivalent about their usefulness [39], suggesting existing resources need to be improved. Further studies are required to evaluate the usability of novel resources and their acceptability to professionals and service users, in order to identify potential improvements. Robust evaluations are needed to establish whether such interventions enable professionals to meet legal standards and increase the reliability of capacity judgements. These types of evidence would support the wider implementation of these interventions and their inclusion in best practice guidelines.

\section{Limitations}

An important limitation of this review is that a single researcher was primarily responsible for study selection, data extraction, quality assessment and data synthesis. The researcher's 
expectations, based on prior clinical experience, may have introduced confirmation bias. However, the first author consulted his co-authors throughout the review process, to raise queries about the search strategy and the results obtained. Although the studies reviewed reported practice carried out by a range of professionals working in various health and social care settings with different groups of service users, the majority of studies focussed on practice relating to two main clinical populations: people with learning disabilities and people with mental health conditions; this should be considered when attempting to generalise the review's findings to other groups. Further research is required to increase our understanding of how professionals complete capacity assessments for different groups of service users. Furthermore, many studies included in the review involved small sample sizes and methodological weaknesses, which limit the validity, reliability and generalisability of their results.

\section{Conclusion}

This review provides confirmatory evidence that health and social care professionals need support to improve the quality of their mental capacity assessments. The review has identified aspects of practice that are inconsistent with the law and potential methods that could be used to facilitate and improve practice. This review has also identified research methodologies that could be used to provide a greater understanding of current practice and to identify practice development needs and potential solutions to meet those needs. Health and social care practitioners, researchers and leaders could use these findings to design practice guidelines, research studies, training programme specifications and practical assessment resources to drive improvements in practice. Novel interventions should be evaluated to ensure they are usable, acceptable and are effective in improving assessment quality, before they are fully implemented. It is hoped that the findings of this review could be used to inform discussions and further debate about the implementation of mental capacity legislation in England and Wales.

\section{Acknowledgments}

This article presents independent research funded by the National Institute for Health Research (NIHR). The views expressed are those of the authors and not necessarily those of the NHS, the NIHR or the Department of Health. Mark Jayes was funded by an NIHR Clinical Doctoral Research Fellowship. 


\section{Declaration of interest}

The authors report no conflicts of interest.

\section{References}

1. Stojan JN, Clay MA, Lypson ML. Assessing patient-centred care through direct observation of clinical encounters. BMJ Qual Saf. 2016;25:135-137.

2. Zuscak SJ, Peisah C, Ferguson A. A collaborative approach to supporting communication in the assessment of decision making capacity. Disabil Rehabil. 2016;38(11):1107-1114.

3. Lepping P, Stanly T, Turner J. Systematic review on the prevalence of lack of capacity in medical and psychiatric settings. Clin Med (Lond). 2015;15(4):337-343.

4. Office of Public Sector Information. Mental Capacity Act 2005. London: OPSI; 2005.

5. Office of Public Sector Information. Mental Capacity Act 2005 paragraph 1. London: OPSI; 2005.

6. Office of Public Sector Information. Mental Capacity Act 2005 paragraph 2(1). London: OPSI; 2005.

7. Office of Public Sector Information. Mental Capacity Act 2005 paragraph 3(1). London: OPSI; 2005.

8. Office of Public Sector Information. Mental Capacity Act 2005 paragraph 1(5). London: OPSI; 2005.

9. Lamont $\mathrm{S}$, Jeon $\mathrm{YH}$, Chiarella M. Assessing patient capacity to consent to treatment: an integrative review of instruments and tools. J Clin Nurs. 2013;22(17-18):23872403.

10. Department of Health. Deprivation of Liberty Safeguards: Code of Practice to Supplement the Main Mental Capacity Act 2005 Code of Practice. London: TSO (The Stationery Office); 2008. 
11. Ryan T, Gardiner C, Bellamy, G, et al. Barriers and facilitators to the receipt of palliative care for people with dementia: The views of medical and nursing staff. Palliative Med. 2012;26(7):879-886.

12. Ruck Keene A. Is mental capacity in the eye of the beholder? Adv in Ment Health and Intellect Disabil. 2017;11(2):30-39.

13. House of Lords. Mental Capacity Act Post-Legislative scrutiny. HL 139, 2014. London: HMSO; 2014.

14. P v Kent County Council [2015] EWCP 89

15. L v J [2010] EWHC 2665 (Fam)

16. CC v KK [2012] EWCOP 2136

17. Willner $\mathrm{P}$, Bridle $\mathrm{J}$, Price $\mathrm{V}$, et al. What do NHS staff learn from training on the Mental Capacity Act (2005)? Legal Criminol Psych. 2010;18(1):83-101.

18. Ferguson A, Duffield G, Worrall L. Legal decision making by people with aphasia: Critical incidents for speech pathologists. Int J Lang Commun Disord. 2010;45(2):244-258.

19. Grant MJ, Booth A. A typology of reviews: an analysis of 14 review types and associated methodologies. Health Info Libr J. 2009;26(2):91-108.

20. NHS Centre for Reviews and Dissemination (CRD) Systematic Reviews: CRD's guidance for undertaking reviews in healthcare. York: CRD; 2009.

21. Clarke G, Harrison K, Holland A, et al. How are Treatment Decisions Made about Artificial Nutrition for Individuals at Risk of Lacking Capacity? A Systematic Literature Review. PLoS One. 2013;8(4): e61475.

22. Hinsliff-Smith K, Spencer R, Walsh D, et al. What do we know about the application of the Mental Capacity Act (2005) in healthcare practice regarding decision-making for frail and older people? A systematic literature review. Health Soc Care Comm. 2017;25(2):295-308.

23. Marshall $\mathrm{H}$, Sprung S. The Mental Capacity Act: a review of the literature. $\mathrm{Br} \mathrm{J}$ Community Nurs. 2016;21(8):406-410. 
24. Mental Health Foundation 2012. Mental Capacity and the Mental Capacity Act 2005. A literature review. Available from:

https://www.mentalhealth.org.uk/publications/mental-capacity-and-mental-capacityact-2005-literature-review

25. Robinson L, Dickinson C, Rousseau N, et al. A systematic review of the effectiveness of advance care planning interventions for people with cognitive impairment and dementia. Age Ageing. 2012;41:263-269.

26. Wilson S. Mental capacity legislation in the UK: systematic review of the experiences of adults lacking capacity and their carers. BJPsych Bulletin. 2017;41:260-266.

27. Moher D, Liberati A, Tetzlaff J, et al. Preferred Reporting Items for Systematic Reviews and Meta-Analyses: The PRISMA Statement. PLoS Medicine. 2009:6(7):e1000097.

28. Critical Appraisal Skills Programme (CASP). Qualitative Research Checklist. 2013 Available from:

http://media.wix.com/ugd/dded87 29c5b002d99342f788c6ac670e49f274.pdf

29. Crombie I. The Pocket Guide to Critical Appraisal. London: BMJ; 2002.

30. Centre for Evidence-Based Management (CEBM) Critical Appraisal of a case study. 2014. Available from: http://www.cebma.org/wp-content/uploads/Critical-AppraisalQuestions-for-a-Case-Study.pdf

31. Braun V, Clarke V. Using thematic analysis in psychology. Qual Res Psychol. 2006;3(2):77-101.

32. Biswas AB, Hiremath A. Mental capacity assessment and 'best interests' decisionmaking in clinical practice: a case illustration. Adv Psychiat Treat. 2010;16:440-447.

33. Cliff $\mathrm{C}, \mathrm{McGraw} \mathrm{C}$. The conduct and process of mental capacity assessments in home health care settings. Br J Community Nurs. 2016;21(11):570-577.

34. Emmett C, Poole M, Bond J, et al. Homeward bound or bound for a home? Assessing the capacity of dementia patients to make decisions about hospital discharge: Comparing practice with legal standards. Int J Law Psychiat. 2013;36:7382. 
35. Guyver P, Hindle P, Harrison J, et al. The Mental Capacity Act 2005: Review of mental capacity assessment in people with proximal femoral fracture. Psychiatrist. 2010;34:284-286.

36. Jayes M, Palmer R, Enderby P. An exploration of mental capacity assessment within acute hospital and intermediate care settings in England: a focus group study. Disabil Rehabil. 2017;39(21): 2148-2157.

37. Jepson M, Laybourne A, Williams $\mathrm{V}$, et al. Indirect payments: when the Mental Capacity act interacts with the personalisation agenda. Health Soc Care Comm. 2016;24(5):623-630.

38. Linn K, Sayer C, O'Connor G, et al. Reflections on mental capacity assessments in general hospitals. BMJ Case Reports. 2013. doi:10.1136/bcr-2012- 008538

39. Marshall H, Sprung S. Community nurse's knowledge, confidence and experience of the Mental Capacity Act in practice. Br J Community Nurs. 2016;21(12):615-622.

40. McCormick M, Bose A, Marinis T. Decision-making capacity in aphasia: SLT's contribution in England. Aphasiology. 2017;31(11):1344-1358.

41. Murrell A, McCalla L. Assessing Decision-making Capacity: The Interpretation and Implementation of the Mental Capacity Act 2005 Amongst Social Care Professionals. Practice: Social Work in Action. 2016;28(1):21-26.

42. Oldreive $\mathrm{W}$, Waight $\mathrm{M}$. Assessment of capacity: reflections from practice. Learn Disabil Pract. 2011;14:31-36.

43. Ramasubramanian L, Ranasinghe N, Ellison J. Evaluation of a structured assessment framework to enable adherence to the requirements of Mental Capacity Act 2005. Br J Learn Disabil. 2011;39:314-320.

44. Ratcliffe D, Chapman M. Health and social care practitioners' experiences of assessing mental capacity in a community learning disability team. $\mathrm{Br} \mathrm{J}$ Learn Disabil. 2016;44:329-336.

45. Scope 2009. A Long Road to Travel: The impact of the Mental Capacity Act on Adults with Complex Needs in Residential Settings. Available from: http://www.scie.org.uk/publications/mca/files/longroadtotravel.pdf 
46. Shah A, Banner N, Heginbotham C, et al. The application of the Mental Capacity Act 2005 among geriatric psychiatry patients: a pilot study. Int Psychogeriatr. 2009;21:922-930.

47. Shah A, Banner N, Newbigging K, et al. The early experience of consultant psychiatrists in application of the Mental Capacity Act: issues for black and minority individuals. Ethn Inequal Health Soc Care. 2009;2:4-10.

48. Shah A, Banner N, Heginbotham C, et al. The early experience of Old Age Psychiatrists in the application of the Mental Capacity Act 2005: a pilot study. Int Psychogeriatr. 2010;22:147-157.

49. Skinner R, Joiner C, Chesters L, et al. Demystifying the process? A multi disciplinary approach to assessing capacity for adults with a learning disability. $\mathrm{Br} \mathrm{J}$ of Learn Disabil. 2011;39:92-97.

50. Sorinmade O, Strathdee G, Wilson C, et al. Audit of fidelity of clinicians to the Mental Capacity Act in the process of capacity assessment and arriving at best interests decisions. Qual Ageing Old Adults. 2011;12:174-179.

51. Spencer BWJ, Wilson G, Okon-Rocha E, et al. Capacity in vacuo: an audit of decision-making capacity assessments in a liaison psychiatry service. BJPsych Bulletin. 2017;41:7-11.

52. Williams, V. et al. (2012) Making Best Interests Decisions: People and Processes [online]. London, Mental Health Foundation. Available from: http://www.mentalhealth.org.uk/content/assets/PDF/publications/BIDS_report_24-0212_FINAL1.pdf?view=Standard [Accessed 29 June 2012].

53. Williams V, Boyle G, Jepson M, et al. Best interests decisions: professional practices in health and social care. Health Soc Care Comm. 2014;22:78-86.

54. Department for Constitutional Affairs. Mental Capacity Act 2005 Code of Practice. London: Department for Constitutional Affairs; 2007.

55. Reuber M, Toerien M, Shaw R, et al. Delivering patient choice in clinical practice: a conversation analytic study of communication practices used in neurology clinics to involve patients in decision-making. Health Serv and Deliv Res. 2015;3(7): DOI: 10.3310/hsdr03070 
56. $\mathrm{PH}$ and a local authority and Z limited and R [2011] EWCOP 1704

57. Norfolk County Council v PB [2014] EWCOP 14

58. Hawley ST, Morris AM. Cultural challenges to engaging patients in shared decision making. Patient Educ Couns. 2017;100(1):18-24.

59. Bunn F, Goodman C, Russell B, et al. Supporting shared decision making for older people with multiple health and social care needs: a realist synthesis. BMC Geriatrics. 2018;18:165.

60. Ripley S, Jones S, Macdonald A. et al. Capacity assessments on medical in-patients referred to social workers for care home placement. Psychiatrist. 2008;32:56-59. 


\begin{tabular}{|c|c|c|c|c|c|}
\hline Study & $\begin{array}{l}\text { Design I } \\
\text { method }\end{array}$ & Population studied & Study aim & Key findings & Study quality limitations \\
\hline $\begin{array}{l}\text { Biswas \& } \\
\text { Hiremath } \\
(2010)[32]\end{array}$ & $\begin{array}{l}\text { Single case } \\
\text { study }\end{array}$ & $\begin{array}{l}\text { Adults with learning } \\
\text { disability in specialist } \\
\text { inpatient unit }(n=1) \text {. }\end{array}$ & $\begin{array}{l}\text { To describe capacity } \\
\text { assessment practice } \\
\text { and good practice in } \\
\text { best interests decision- } \\
\text { making. }\end{array}$ & $\begin{array}{l}\text { Strategies used to facilitate } \\
\text { communication with service- } \\
\text { user. }\end{array}$ & $\begin{array}{l}\text { - } \quad \text { Data collection methods unclear; } \\
\text { - } \quad \text { Lack of researcher reflexivity; } \\
\text { - Limited generalizability due to } \\
\text { design. }\end{array}$ \\
\hline $\begin{array}{l}\text { Cliff \& McGraw } \\
\text { (2016) [33] }\end{array}$ & $\begin{array}{l}\text { Qualitative: } \\
\text { interviews }\end{array}$ & $\begin{array}{l}\text { Senior community } \\
\text { nurses }(n=14) \text {, } \\
\text { occupational therapists } \\
(n=3) \text {, physiotherapists } \\
(n=6) \text { at a London } \\
\text { health trust. }\end{array}$ & $\begin{array}{l}\text { To identify facilitators } \\
\text { and inhibitors to } \\
\text { capacity assessment. }\end{array}$ & $\begin{array}{l}\text { - Facilitators and inhibitors to } \\
\text { good practice identified; } \\
\text { Descriptions of support given to } \\
\text { aid decision making during } \\
\text { capacity assessment. }\end{array}$ & $\begin{array}{l}\text { - } \quad \text { Sampling strategy unclear; } \\
\text { - } \quad \text { Limited description of data } \\
\text { analysis methods; } \\
\text { - } \quad \text { Lack of researcher reflexivity. }\end{array}$ \\
\hline $\begin{array}{l}\text { Emmett et al. } \\
\text { (2013) [34] }\end{array}$ & $\begin{array}{l}\text { Qualitative: } \\
\text { ethnography, } \\
\text { interviews, } \\
\text { focus } \\
\text { groups. }\end{array}$ & $\begin{array}{l}\text { Hospital patients with } \\
\text { dementia }(n=28) ; \\
\text { carers }(n=28) ; \text { health } \\
\text { and social care } \\
\text { professionals }(n=35) \text {. }\end{array}$ & $\begin{array}{l}\text { To describe capacity } \\
\text { assessment practice in } \\
\text { relation to legal } \\
\text { standards derived from } \\
\text { MCA. }\end{array}$ & $\begin{array}{l}\text { - Only } 50 \% \text { patients formally } \\
\text { assessed; } \\
\text { - } \text { Practice variable but generally } \\
\text { not consistent with } \\
\text { requirements of MCA. }\end{array}$ & $\begin{array}{l}\text { - Limited description of data } \\
\text { analysis methods; } \\
\text { - No discussion of deviant cases } \\
\text { - } \quad \text { Lack credibility of findings; } \\
\text { - } \quad \text { researcher reflexivity. }\end{array}$ \\
\hline $\begin{array}{l}\text { Guyver et al. } \\
\text { (2010) [35] }\end{array}$ & $\begin{array}{l}\text { Case note } \\
\text { audit }\end{array}$ & $\begin{array}{l}\text { Hospital orthopaedic } \\
\text { patients }(n=50)\end{array}$ & $\begin{array}{l}\text { To compare practice } \\
\text { against standards } \\
\text { derived from MCA, } \\
\text { before and after } \\
\text { training intervention. }\end{array}$ & $\begin{array}{l}\text { Improvement in documented } \\
\text { practice following intervention. }\end{array}$ & $\begin{array}{l}\text { - } \quad \text { Sampling strategy unclear; } \\
\text { - } \quad \text { Limited description of } \\
\text { participants; } \\
\text { - Unable to establish causal } \\
\text { relationship between intervention } \\
\text { and results, due to design. }\end{array}$ \\
\hline $\begin{array}{l}\text { Jayes, Palmer } \\
\text { \& Enderby } \\
(2016)[36]\end{array}$ & $\begin{array}{l}\text { Qualitative: } \\
\text { focus groups }\end{array}$ & $\begin{array}{l}\text { Multidisciplinary staff } \\
\text { in acute hospital and } \\
\text { intermediate care } \\
\text { settings in northern } \\
\text { England }(n=13)\end{array}$ & $\begin{array}{l}\text { To understand how } \\
\text { health and social care } \\
\text { staff assess mental } \\
\text { capacity in these } \\
\text { settings. }\end{array}$ & 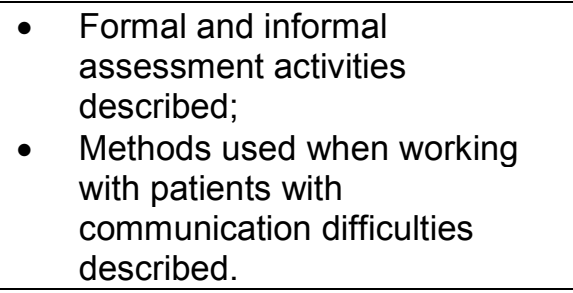 & $\begin{array}{l}\text { - Convenience sampling; some } \\
\text { professional groups not } \\
\text { represented in sample. }\end{array}$ \\
\hline $\begin{array}{l}\text { Jepson et al. } \\
(2016)[37]\end{array}$ & $\begin{array}{l}\text { Qualitative: } \\
\text { interviews }\end{array}$ & $\begin{array}{l}\text { Social work } \\
\text { professionals }(n=67) \text {; } \\
\text { adults managing } \\
\text { financial affairs of } \\
\text { people lacking } \\
\text { capacity }(n=18)\end{array}$ & $\begin{array}{l}\text { To explore how social } \\
\text { care professionals } \\
\text { manage social care } \\
\text { direct payments } \\
\text { system for people who }\end{array}$ & $\begin{array}{l}\text { - Most practitioners appeared to } \\
\text { understand and comply with } \\
\text { MCA; } \\
\text { Practitioners confused capacity } \\
\text { to consent to payments with } \\
\text { capacity to manage payments. }\end{array}$ & $\begin{array}{l}\text { - } \quad \text { Limited description of data } \\
\text { collection and analysis methods; } \\
\text { - } \quad \text { Lack of researcher reflexivity. }\end{array}$ \\
\hline
\end{tabular}




\begin{tabular}{|c|c|c|c|c|c|}
\hline Study & $\begin{array}{l}\text { Design I } \\
\text { method }\end{array}$ & Population studied & Study aim & Key findings & Study quality limitations \\
\hline & & & $\begin{array}{l}\text { lack capacity to } \\
\text { consent to them. }\end{array}$ & & \\
\hline $\begin{array}{l}\text { Linn et al. } \\
\text { (2013) [38] }\end{array}$ & Case studies & $\begin{array}{l}\text { Patients with mental } \\
\text { health conditions on } \\
\text { general medical } \\
\text { hospital wards }(n=2) \text {. }\end{array}$ & $\begin{array}{l}\text { To describe influence } \\
\text { of mental disorders on } \\
\text { mental capacity, role } \\
\text { of specialist } \\
\text { assessors. }\end{array}$ & $\begin{array}{l}\text { Assessment content and } \\
\text { outcome differed between two } \\
\text { professional groups (non- } \\
\text { specialist vs specialist). }\end{array}$ & $\begin{array}{l}\text { - } \quad \text { Data collection methods unclear; } \\
\text { - } \quad \text { Lack of researcher reflexivity; } \\
\text { Limited generalizability due to } \\
\text { design. }\end{array}$ \\
\hline $\begin{array}{l}\text { Marshall \& } \\
\text { Sprung } \\
(2016)[39]\end{array}$ & $\begin{array}{l}\text { Mixed } \\
\text { methods: } \\
\text { electronic } \\
\text { survey, focus } \\
\text { group and } \\
\text { paired } \\
\text { interview }\end{array}$ & $\begin{array}{l}\text { Community nurses in } \\
\text { single trust in North } \\
\text { West England (survey: } \\
n=60 ; \text { focus group: } \\
n=7 ; \text { paired interview: } \\
n=2 \text { ) }\end{array}$ & $\begin{array}{l}\text { To understand the } \\
\text { experience of } \\
\text { community nurses } \\
\text { using the MCA in } \\
\text { clinical practice. }\end{array}$ & $\begin{array}{l}\text { Descriptions of collaborative } \\
\text { working with other } \\
\text { professionals and patient's } \\
\text { family during capacity } \\
\text { assessments; } \\
\text { Documentation methods } \\
\text { described. }\end{array}$ & $\begin{array}{l}\text { - } \quad \text { Sampling strategy unclear; } \\
\text { - } \quad \text { Limited description of data } \\
\text { analysis methods; } \\
\text { - } \quad \text { Low response rate to survey. }\end{array}$ \\
\hline $\begin{array}{l}\text { McCormick, } \\
\text { Bose \& } \\
\text { Marinis (2017) } \\
{[40]}\end{array}$ & $\begin{array}{l}\text { Mixed } \\
\text { methods: } \\
\text { electronic } \\
\text { survey }\end{array}$ & $\begin{array}{l}\text { Speech and Language } \\
\text { Therapists (SLTs) in } \\
\text { England }(n=56)\end{array}$ & $\begin{array}{l}\text { To describe the } \\
\text { involvement of SLTs in } \\
\text { capacity assessments } \\
\text { for people with } \\
\text { aphasia (PwA). }\end{array}$ & $\begin{array}{l}\text { PwA may not always receive } \\
\text { communication support during } \\
\text { capacity assessments. }\end{array}$ & $\begin{array}{l}\text { - } \quad \text { Sampling strategy unclear; } \\
\text { - Survey response rate not } \\
\text { provided; } \\
\text { - Limited description of } \\
\text { participants; }\end{array}$ \\
\hline $\begin{array}{l}\text { Murrell \& } \\
\text { McCalla } \\
(2016)[41]\end{array}$ & $\begin{array}{l}\text { Qualitative: } \\
\text { interviews }\end{array}$ & $\begin{array}{l}\text { Social care } \\
\text { professionals: social } \\
\text { workers }(n=5) ; \text { field } \\
\text { work assessor }(n=1)\end{array}$ & $\begin{array}{l}\text { To explore how social } \\
\text { care professionals } \\
\text { interpret the MCA and } \\
\text { assess capacity. }\end{array}$ & $\begin{array}{l}\text { Examples of practice provided } \\
\text { that are not consistent with the } \\
\text { MCA; } \\
\text { Different methods used to } \\
\text { maximise capacity / increase } \\
\text { assessment quality. }\end{array}$ & $\begin{array}{l}\text { - } \quad \text { Recruitment strategy unclear; } \\
\text { - } \quad \text { Data collection and analysis } \\
\text { methods unclear; } \\
\text { - } \quad \text { Relationship between researcher } \\
\text { and participants unclear. }\end{array}$ \\
\hline $\begin{array}{l}\text { Oldreive \& } \\
\text { Waight (2011) } \\
{[42]}\end{array}$ & Case series & $\begin{array}{l}\text { Adults with learning } \\
\text { disability }(n=18) \text {. }\end{array}$ & $\begin{array}{l}\text { To describe use of and } \\
\text { outcomes from } \\
\text { structured assessment } \\
\text { pathway. }\end{array}$ & $\begin{array}{l}\text { Pathway enabled assessment } \\
\text { to be adapted to cognitive and } \\
\text { communication needs; }\end{array}$ & $\begin{array}{l}\text { - } \quad \text { Data collection methods unclear; } \\
\text { - } \quad \text { Lack of researcher reflexivity; } \\
\text { - Limited generalizability due to } \\
\text { design. }\end{array}$ \\
\hline $\begin{array}{l}\text { Ramasubra- } \\
\text { manian et al. } \\
(2011)[43]\end{array}$ & $\begin{array}{l}\text { Case note } \\
\text { audit }\end{array}$ & $\begin{array}{l}\text { Adults with learning } \\
\text { disability in specialist } \\
\text { inpatient unit }(n=20) \text {. }\end{array}$ & $\begin{array}{l}\text { To compare practice } \\
\text { before and after } \\
\text { intervention (structured }\end{array}$ & $\begin{array}{l}\text { Significant improvement in } \\
\text { practice following intervention. }\end{array}$ & $\begin{array}{ll}\text { - } & \text { Incomplete data set; } \\
\text { - } & \text { Unclear who collected data; } \\
\text { - } & \text { Unable to establish causal link } \\
& \text { between intervention and results. }\end{array}$ \\
\hline
\end{tabular}




\begin{tabular}{|c|c|c|c|c|c|}
\hline Study & $\begin{array}{l}\text { Design I } \\
\text { method }\end{array}$ & Population studied & Study aim & Key findings & Study quality limitations \\
\hline & & & $\begin{array}{l}\text { assessment } \\
\text { framework). }\end{array}$ & & \\
\hline $\begin{array}{l}\text { Ratcliffe \& } \\
\text { Chapman } \\
(2016)[44]\end{array}$ & $\begin{array}{l}\text { Qualitative: } \\
\text { interviews }\end{array}$ & $\begin{array}{l}\text { Health and social care } \\
\text { practitioners working in } \\
\text { a community learning } \\
\text { disability team }(n=8) \text {. }\end{array}$ & $\begin{array}{l}\text { To identify challenges / } \\
\text { barriers to good } \\
\text { practice and ways to } \\
\text { overcome these. }\end{array}$ & $\begin{array}{l}\text { - Systemic, process and person- } \\
\text { specific challenges and barriers } \\
\text { identified; } \\
\text { - Assessment activities } \\
\text { described. }\end{array}$ & $\begin{array}{l}\text { - } \quad \text { Sampling strategy unclear; } \\
\text { - } \quad \text { Limited description of data } \\
\text { collection methods; } \\
\text { - } \quad \text { Lack of researcher reflexivity. }\end{array}$ \\
\hline $\begin{array}{l}\text { Scope (2009) } \\
{[45]}\end{array}$ & $\begin{array}{l}\text { Qualitative: } \\
\text { ethnography, } \\
\text { interviews, } \\
\text { completion of } \\
\text { "work } \\
\text { books". }\end{array}$ & $\begin{array}{l}\text { Disabled adults with } \\
\text { complex needs in } \\
\text { residential settings } \\
(\mathrm{n}=6) ; \text { family members } \\
\text { and professionals ( } \mathrm{n} \\
\text { not stated). }\end{array}$ & $\begin{array}{l}\text { To explore the impact } \\
\text { of the MCA on } \\
\text { disabled people. }\end{array}$ & $\begin{array}{l}\text { - Lack of formal capacity } \\
\text { assessment reported; } \\
\text { Practice reported that is not } \\
\text { consistent with MCA. }\end{array}$ & $\begin{array}{l}\text { Data collection and analysis } \\
\text { methods unclear; } \\
\text { - } \quad \text { Lack of researcher reflexivity; } \\
\text { - } \quad \text { Authors say results unlikely to be } \\
\text { generalizable. }\end{array}$ \\
\hline $\begin{array}{l}\text { Shah et al. } \\
(2009 a)[46]\end{array}$ & $\begin{array}{l}\text { Case note } \\
\text { review }\end{array}$ & $\begin{array}{l}\text { Patients of old age } \\
\text { psychiatrists }(n=37) .\end{array}$ & $\begin{array}{l}\text { To investigate old age } \\
\text { psychiatrists' } \\
\text { experience of } \\
\text { implementing the } \\
\text { MCA. }\end{array}$ & $\begin{array}{l}\text { - Assessment practice not } \\
\text { always consistent with the } \\
\text { MCA; } \\
\text { Consideration of } \\
\text { culture/ethnicity, religion, } \\
\text { language variable. }\end{array}$ & $\begin{array}{l}\text { Possible selection bias: } \\
\text { psychiatrists who responded } \\
\text { selected notes for audit } \\
\text { themselves. }\end{array}$ \\
\hline $\begin{array}{l}\text { Shah et al. } \\
(2009 b)[47] \\
\text { (additional } \\
\text { data reported } \\
\text { in Shah et al. } \\
\text { (2010) [48] }\end{array}$ & $\begin{array}{l}\text { Mixed } \\
\text { methods: } \\
\text { survey }\end{array}$ & $\begin{array}{l}\text { Consultants in old age } \\
\text { psychiatry }(n=52) ; \\
\text { consultants in other } \\
\text { psychiatric specialities } \\
(n=113) .\end{array}$ & $\begin{array}{l}\text { To explore } \\
\text { psychiatrists' } \\
\text { experience of } \\
\text { implementing the MCA } \\
\text { with black and ethnic } \\
\text { minority groups. }\end{array}$ & $\begin{array}{l}\text { Descriptions of practice } \\
\text { involving this patient population } \\
\text { provided; } \\
\text { Practice that is legally } \\
\text { compliant and not compliant } \\
\text { identified. }\end{array}$ & $\begin{array}{l}\text { Low response rate; } \\
\text { - No description of sample, } \\
\text { therefore unclear if results } \\
\text { generalizable; } \\
\text { Data analysis method flawed. }\end{array}$ \\
\hline $\begin{array}{l}\text { Skinner et al. } \\
(2010) \text { [49] }\end{array}$ & $\begin{array}{l}\text { Case series } \\
\text { with } 2 \text { case } \\
\text { studies }\end{array}$ & $\begin{array}{l}\text { Adults with learning } \\
\text { disability referred to } \\
\text { ophthalmology }(n=17)\end{array}$ & $\begin{array}{l}\text { To describe new } \\
\text { structured assessment } \\
\text { system and outcomes } \\
\text { from use of system. }\end{array}$ & $\begin{array}{l}\text { - New system enabled } \\
\text { assessment to be adapted to } \\
\text { patient's communication and } \\
\text { cognitive needs; } \\
\text { - System involved carers in } \\
\text { assessment process. }\end{array}$ & $\begin{array}{l}\text { - } \quad \text { Lack of reflexivity; } \\
\text { - } \quad \text { Limited generalizability due to } \\
\text { design. }\end{array}$ \\
\hline $\begin{array}{l}\text { Sorinmade et } \\
\text { al. (2011) [50] }\end{array}$ & $\begin{array}{l}\text { Case note } \\
\text { review }\end{array}$ & $\begin{array}{l}\text { Patients under care of } \\
\text { Community Mental } \\
\text { Health Teams or }\end{array}$ & $\begin{array}{l}\text { To investigate health } \\
\text { care professionals' }\end{array}$ & $\begin{array}{l}\text { Descriptions of legally } \\
\text { compliant and non-compliant } \\
\text { practice provided. }\end{array}$ & $\begin{array}{l}\text { - } \quad \text { Possible selection bias; } \\
\text { - Incomplete sample; }\end{array}$ \\
\hline
\end{tabular}




\begin{tabular}{|c|c|c|c|c|c|}
\hline Study & $\begin{array}{l}\text { Design I } \\
\text { method }\end{array}$ & Population studied & Study aim & Key findings & Study quality limitations \\
\hline & & $\begin{array}{l}\text { hospital geriatricians } \\
(n=68) \text {. }\end{array}$ & $\begin{array}{l}\text { compliance with MCA } \\
\text { principles. }\end{array}$ & & $\begin{array}{l}\text { - Relationship between audit } \\
\text { professionals and clinicians } \\
\text { unclear. }\end{array}$ \\
\hline $\begin{array}{l}\text { Spencer et al. } \\
\text { (2017) [51] }\end{array}$ & $\begin{array}{l}\text { Case note } \\
\text { audit }\end{array}$ & $\begin{array}{l}\text { Liaison Psychiatrists } \\
\text { and Psychiatric Liaison } \\
\text { Nurses working at a } \\
\text { London hospital trust } \\
\text { (n=not reported). }\end{array}$ & $\begin{array}{l}\text { To audit } \\
\text { documentation of } \\
\text { assessments against } \\
\text { legal standards before, } \\
\text { during and after an } \\
\text { educational } \\
\text { intervention. }\end{array}$ & $\begin{array}{ll}\text { - } & \text { Intervention did not have } \\
\text { significant effect on practice; } \\
\text { - } \quad \text { Factors affecting assessment } \\
\text { outcomes identified. }\end{array}$ & $\begin{array}{l}\text { - Limited description of data } \\
\text { collection and analysis methods. }\end{array}$ \\
\hline $\begin{array}{l}\text { Williams et al. } \\
\text { (2012) [52] (on } \\
\text { behalf of } \\
\text { Mental Health } \\
\text { Foundation). } \\
\text { Additional data } \\
\text { reported in } \\
\text { Williams et al., } \\
\text { (2014) [53] }\end{array}$ & $\begin{array}{l}\text { Mixed } \\
\text { methods: } \\
\text { survey and } \\
\text { qualitative } \\
\text { interviews }\end{array}$ & $\begin{array}{l}\text { Health and social care, } \\
\text { legal professionals } \\
\text { involved in MCA } \\
\text { implementation (online } \\
\text { survey } n=385 ; \\
\text { telephone interviews } \\
n=68 ; \text { face-to-face } \\
\text { interviews } n=44 \text { ) }\end{array}$ & $\begin{array}{l}\text { To describe current } \\
\text { practice in best } \\
\text { interests decision- } \\
\text { making. }\end{array}$ & $\begin{array}{ll} & \text { Assessment practice not } \\
\text { consistent with MCA identified; } \\
\text { - Assessors' concerns about } \\
\text { their practice identified. }\end{array}$ & $\begin{array}{l}\text { Possible selection bias for } \\
\text { interview sample; } \\
\text { - } \quad \text { Limited description of data } \\
\text { analysis methods; } \\
\text { - } \quad \text { Lack of researcher reflexivity. }\end{array}$ \\
\hline
\end{tabular}

Table 1: Characteristics of included studies 


\begin{tabular}{|c|c|}
\hline Themes & Subthemes \\
\hline Preparation for assessment & $\begin{array}{ll}\text { - } & \text { Choice of assessor } \\
\text { - } & \text { Information gathering }\end{array}$ \\
\hline $\begin{array}{l}\text { Capacity assessment } \\
\text { processes }\end{array}$ & $\begin{array}{l}\text { - Informal and formal processes } \\
\text { - } \quad \text { Practice that is not compliant with the MCA }\end{array}$ \\
\hline Supported decision-making & $\begin{array}{l}\text { - } \text { Adjustments to the process } \\
\text { - Use of information } \\
\text { - Supporting people with communication needs } \\
\text { - } \quad \text { Consideration of cultural, ethnic and religious factors }\end{array}$ \\
\hline $\begin{array}{l}\text { Interventions to facilitate or } \\
\text { improve practice }\end{array}$ & $\begin{array}{l}\text { - Use of strategies } \\
\text { - Use of novel resources }\end{array}$ \\
\hline
\end{tabular}

Table 2: Themes and subthemes identified within reviewed studies 
Records identified through database searching

$$
(n=701)
$$

Additional records identified through other sources

$$
(n=64)
$$

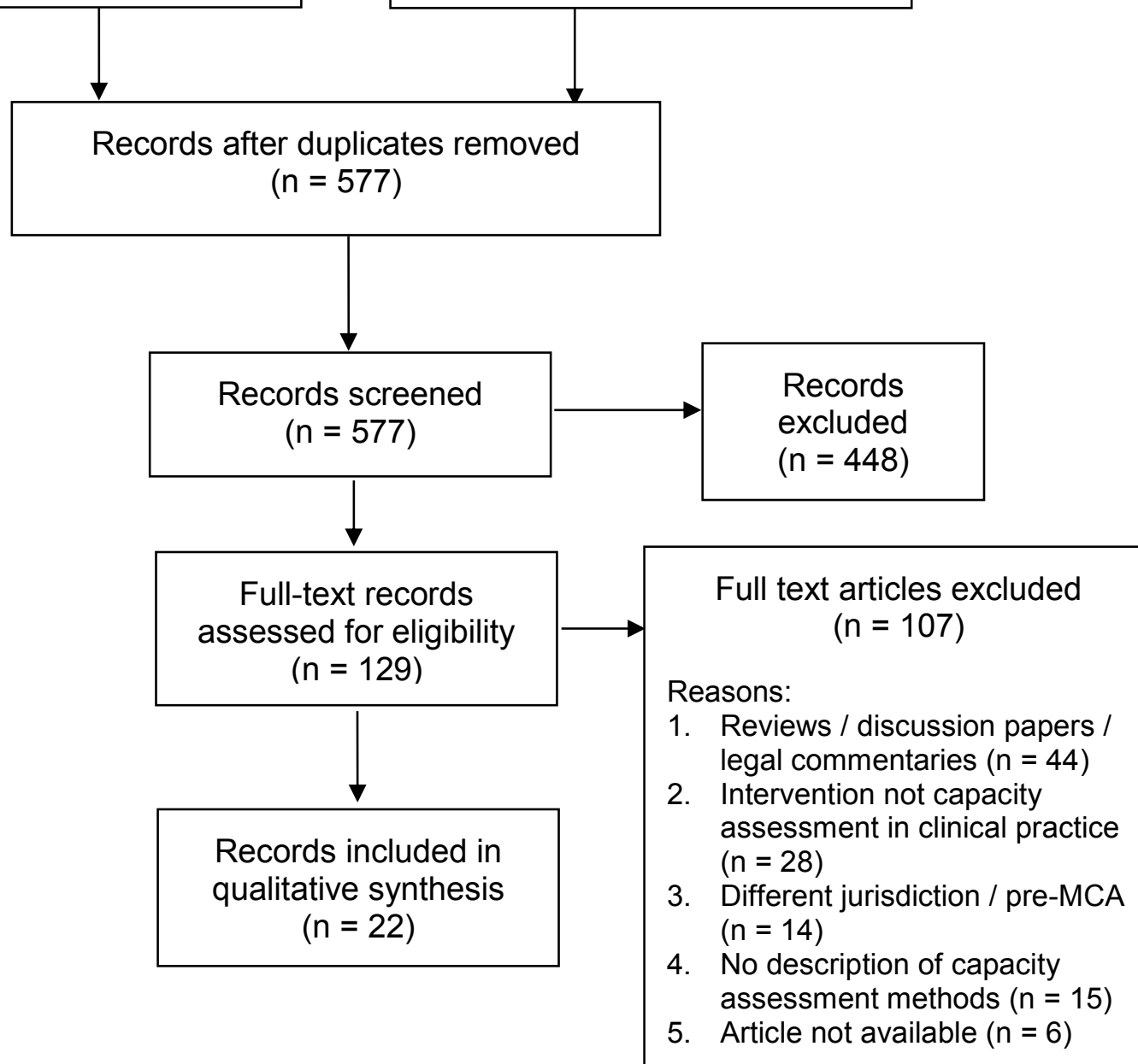

Figure 1: PRISMA flow diagram documenting study selection process 